\title{
Diversity of lactic acid bacteria associated with raw yak (Bos grunniens) milk produced in Pakistan
}

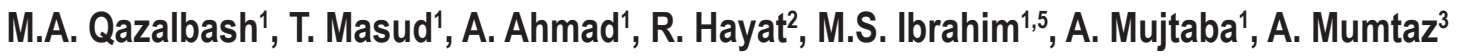 \\ and M.J. Asad ${ }^{4}$ \\ Pir Mehr Ali Shah Arid Agriculture University, ${ }^{1}$ Institute of Food and Nutritional Sciences, ${ }^{2}$ Institute of Soil Sciences \\ Shamsabad, Muree Road, Rawalpindi 46000, Punjab, Pakistan \\ ${ }^{3}$ National Agricultural Research Centre (NARC), Food Sciences Research Institute \\ Centre Park Road, Islamabad 44000, Pakistan \\ ${ }^{4}$ Pir Mehr Ali Shah Arid Agriculture University, Institute of Biochemistry and Biotechnology \\ Shamsabad, Muree Road, Rawalpindi 46000, Punjab, Pakistan
}

KEY WORDS: biodiversity, Gilgit-Baltistan, 16S rRNA gene sequencing, phenotypic variation, probiotics, yaks

Received: 27 March 2020

Revised: 30 January 2021

Accepted: 10 February 2021

${ }^{5}$ Corresponding author:

e-mail: choudhary.mohammad@hotmail.com

\begin{abstract}
Yak (Bos grunniens) milk and its associated products are being used in high altitudes of Northern Pakistan. The aim of the study was to elucidate the diversity of lactic acid bacteria (LAB) isolated from raw yak milk. In total, 88 isolates were characterized according to their phenotypic, physiological and biochemical properties. The abundance of genera from the highest to the lowest was lactobacilli (56\%) followed by enterococci $(36 \%)$ and lactococci ( $8 \%)$. Among these isolates, 9 different species were recognized by studying their biochemical characterization with the use of API $50 \mathrm{CHL}$ systems. The dominance of species included Lactobacillus paracasei subsp. tolerans (19\%) followed by Lactobacillus plantarum and Enterococcus durans (17\%), Enterococcus faecium (11\%), Lactobacillus casei (9\%), Enterococcus hirae and Lactococcus lactis (8\%), Lactobacillus delbrueckii subsp. bulgaricus (7\%) and Lactobacillus sakei (3\%). Identification of 30 representative strains was further confirmed by $16 \mathrm{~S}$ rRNA gene sequence analysis. So, a foundation for developing local starter cultures of LAB for the production of fermented products from yak milk is provided.
\end{abstract}

\section{Introduction}

Yak is classified as Bos grunniens or Poephagus grunniens and is also called the ship of cold regions. Yak is normally found at altitudes between 2000 and $5000 \mathrm{~m}$. The areas where they are domesticated include the Hindukush and Karakoram in Afghanistan and Pakistan, the Himalayas in Bhutan, India and Nepal, Tibetan plateau of China and Mongolia. The total estimated population of yaks around the globe is 14.2 million. About $92-94 \%$ of all yaks are found in China making this country a leader in the yak production (Luming et al., 2008). In Pakistan, yaks are confined to the higher altitudes of Northern areas (now Gilgit-Baltistan) and Chitral. Here their key habitats are the Hindu Kush, Pamir, Hamadans and Karakoram. Regionally yaks are named Bapoo in Gilgit and Astore, Dong in Baltistan and Terminy in Hunza, Nagar and Gojal. A very few reports on the total number of yaks in Pakistan have been published so far. Recently Jasra et al. (2016) reported 25802 yaks in the territories of Gilgit-Baltistan.

There is a growing interest in microorganisms occurring in foods, primarily due to the biotechnological potential of new bacterial species and strains. 
Natural microflora of yak milk represents various genera of bacteria, yeasts and moulds. Certain lactic acid bacteria $(\mathrm{LAB})$ are widely distributed in nature and occur naturally as indigenous microflora in raw milk, yoghurt and others. LAB is important in the food and dairy industries because the lactic acid and other organic acids produced by these bacteria act as natural preservatives as well as flavour enhancers. These bacteria are the major component of the starters used in fermentation, especially for dairy products, and some of them are also natural components of the gastrointestinal microflora (Coeuret et al., 2003).

Foods containing live microorganisms which deliver health benefits through maintaining or improving the microbial balance in the gastrointestinal tract (GIT) are termed as probiotics. Lactobacilli and Bifidobacteria are the best-known probiotic genera to confer health benefits beyond their technological characteristics. The dairy industry is keen to consider new potentials to broaden the range of its product variety. As a result, isolation, identification and characterization of LAB connected to lesserknown native products from various regions have been documented. These include Dahi from Indo-Pak (Mahmood et al., 2013), Rob of Sudan (Abdelgadir et al., 2001), Amasi of Zimbabwe (Gran et al., 2003), Kule Naoto of Kenya (Mathara et al., 2004), Romanian fermented kinds of milk (Zamfir et al., 2006) and Laban of Lebanon (Chammas et al., 2006). Yaks being an integral part of the livelihood of far remote areas of Gilgit-Baltistan can survive harsh environmental conditions. The indigenous microbiota from such environment may contribute to the current limited organoleptic variations of the fermented end products as Lactobacillus bulgaricus and Streptococcus thermophilus that are widely used by the industry in the production of yoghurt. So far, there has not been any study investigating the occurrence and characterization of wild strains of LAB from yak milk in this region of Pakistan. As it is well documented that geographical variation and environmental factors of the region also influence the genetic variation of indigenous microbiota. Therefore, this study may provide an opportunity to assess the incidence of wild strains of LAB from yak milk from this region.

\section{Material and methods}

\section{Sample collection}

With the application of aseptic techniques, a total of 33 raw yak milk samples were collected randomly from individual households from 3 different districts of Gilgit-Baltistan including Nalter
(4603 m/Gilgit), Shimshal (3080 m/Hunza) and Hisper (2702 m/Nager) (Figure 1). Samples were collected from August to November of 2015/2016. Each collected sample (10-20 ml) was tightly closed and kept in an icebox and immediately transferred to the laboratory for microbial analysis.

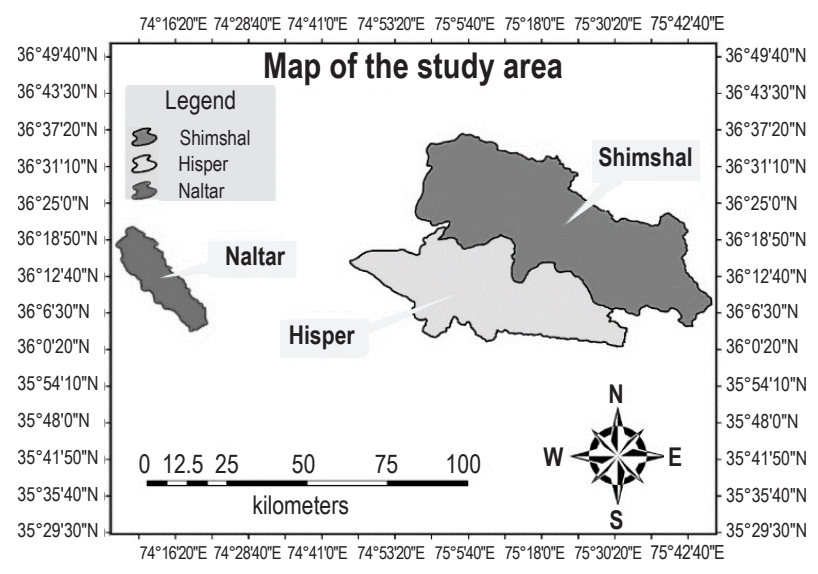

Figure 1. The yak milk sample collection areas from 3 different districts of Gilgit-Baltistan, Pakistan.

\section{Isolation of lactic acid bacteria}

Selective media of MRS (de Man Rogosa Sharpe) and M-17 supplied by Oxoid (Hampshire, UK) prepared according to instructions of manufacturers were used for isolation of LAB by pour plate method following appropriate serial dilutions. These plates were incubated at 10,37 and $42{ }^{\circ} \mathrm{C}$ for 24 to $48 \mathrm{~h}$ under partially anaerobic conditions with the help of a candled extension jar. Single and distinct colonies were chosen and again cultured on the respective agar media and incubated for 24 to $48 \mathrm{~h}$ to obtain the pure culture of the isolates. The identification of these isolates was made according to their morphological and biochemical characteristics according to Bergey's Manual of Systematic Bacteriology (Kandler and Weiss, 1986).

\section{Biochemical characterization of lactic acid bacteria}

The obtained isolates were additionally identified with the use of $\mathrm{API}^{\circledR} 50 \mathrm{CH}$ strips (bioMerieux, Marcy Etoile, France). Instructions of the manufacturer were followed to undertake the test; results were read after $24-48 \mathrm{~h}$ of incubation at $30^{\circ} \mathrm{C}$. Identification was accomplished by comparing the results on the software provided by the manufacturer. The results were analysed according to the biochemical profiles registered in the APIweb $^{\circledR}$ database (bioMerieux, Marcy Etoile, France). 


\section{Molecular identification of isolates}

For confirmation of partially identified strains, 16S rRNA regions of the strains were amplified in poly merase chain reaction (PCR) with the use of previously reported (Liu et al., 2012) set of universal primers namely: 27F (5'-AGAGTTTGATCMTGGCTCAG-3') and 1492R (5'-TACGGYTACCTTGTTACGACTT-3').

For DNA template preparation, individual colonies of the freshly grown strains were picked with sterile toothpicks and suspended into $10 \mu 11 \times \mathrm{TE}$ buffer and incubated in thermal cycler (Eppendorf Mastercycler; Eppendorf, Hamburg, Germany) at $80^{\circ} \mathrm{C}$ for $15 \mathrm{~min}$. Later they were centrifuged in the minicentrifuge (Extra Gene Inc., Taichung, Taiwan) for about $5 \mathrm{~min}$ at $10000 \mathrm{~g}$ and $4{ }^{\circ} \mathrm{C}$ then used as a template for PCR reaction.

For the amplification of $16 \mathrm{~S}$ rRNA, a total reaction mixture of $50 \mu \mathrm{l}$ was prepared containing $28 \mu 1$ nano pure water, $5 \mu \mathrm{l}$ Taq Buffer $(10 \times$ with $\mathrm{KCl}), 3 \mu \mathrm{l} \mathrm{MgCl}(25 \mathrm{mM}), 1 \mu \mathrm{dNTPs}, 5 \mu \mathrm{l}$ each of primer $(10 \mathrm{pmol} / \mu \mathrm{l}), 1 \mu \mathrm{l}$ Taq polymerase $(5 \mathrm{U} / \mu \mathrm{l})$ and $2 \mu 1$ DNA template. The amplification program of PCR mixture included an initial denaturation at $94{ }^{\circ} \mathrm{C}$ for $2 \mathrm{~min}$ followed by 35 cycles of denaturation at $94{ }^{\circ} \mathrm{C}$ for $1 \mathrm{~min}$, annealing at $56^{\circ} \mathrm{C}$ for $1 \mathrm{~min}$ and elongation at $72^{\circ} \mathrm{C}$ for $90 \mathrm{~s}$, the reaction was terminated after a final extension of $72{ }^{\circ} \mathrm{C}$ for 5 min.

\section{S rRNA sequence analysis of selected strains}

Identification of potential strains were further confirmed through 16s rRNA gene sequencing analysis. For this purpose, the amplified products were purified with the use of Gene JET ${ }^{\mathrm{TM}}$ PCR Purification Kit (Thermo Fisher Scientific, Waltham, MO, USA) following the manufacturer's instructions. The amplified PCR product was sent to Macrogen Inc. (Seoul, South Korea) for sequencing purpose. Latterly, the resulted sequences of each strain with forward and reverse primers were assembled by applying the BioEdit version 7.2.5 assembly software programme (Hall, 1999) and the consensus sequences were compared with previously deposited sequences in DNA Data Bank of Japan (DDBJ) using the BLAST algorithm. Finally, the sequences were submitted to the National Centre for Biotechnology Information (NCBI, www.ncbi.nlm.nih.gov) for the acquisition of accession numbers. The phylogenetic tree was build based on the neighbouring joining technique with the application of Molecular Evolutionary Genetics Analysis (MEGA) 6 software (Tamura et al., 2013).

\section{Results}

A total of 88 Gram-positive and catalase-negative isolates considered as presumptive LAB were purified by successive sub-culturing on their respective media and selected for further identification and characterization. Majority of LAB were recovered from MRS-agar plates as compared to M-17 media. Moreover, MRS further allowed for the isolation of genius Lactobacillus along with the isolation of some species of Enterococcus. Similarly, none of the species of Lactobacillus was isolated from M-17 agar. A comparatively high incidence of LAB was recovered from the samples collected from Nulter (36 isolates), followed by Shimshal and Hisper (28 and 24 isolates, respectively). The distribution frequency of LAB from three different sampling areas is presented in Figure 2 (inner ring).

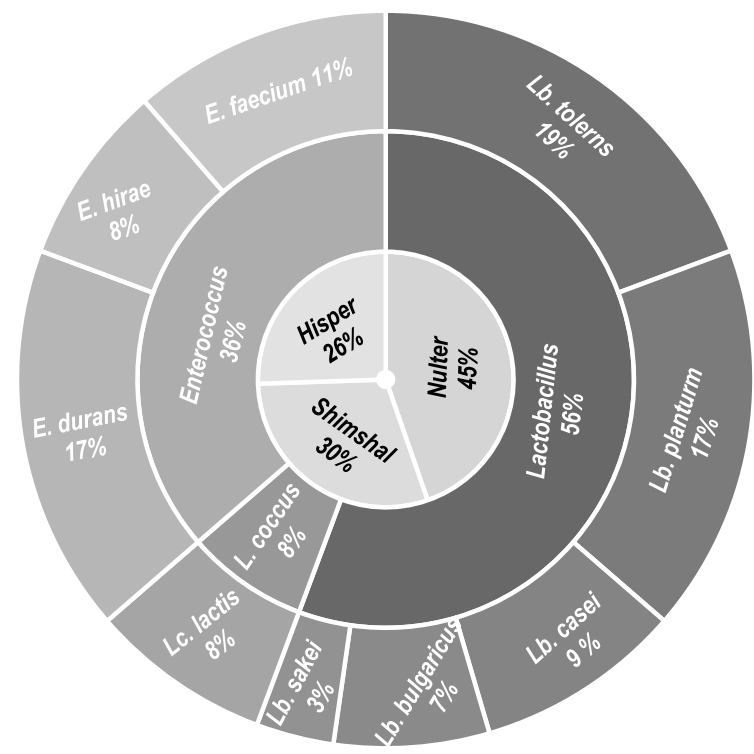

Figure 2. Biodiversity pie chart of lactic acid bacteria (LAB) isolated from raw yak milk collected from 3 different sampling areas in Pakistan; the inner ring shows the distribution frequency from areas; the middle ring shows the percentage of each identified genus; the outer ring shows the percentage of isolated species.

Initially, the identification of all these isolates was made in accordance to their morphological, physiological, biochemical and cultural characteristics. By means of their phenotypic studies, the cocci and rod-shaped isolates were further classified into three genera namely Lactobacillus, Enterococcus and Lactococcus. Different shapes of colonies were observed with smooth surfaces and regular margins. Only Lb. lactis and enterococci were able to grow at $10^{\circ} \mathrm{C}$, while all the isolates except enterococci and $L b$. delbureckii subsp. bulgaricus did not show any growth at $45{ }^{\circ} \mathrm{C}$. 
The morphological, physiological and biochemical diversity of 88 isolates is reflected in Table 1, and the distribution frequencies of prevalent genera of LAB isolated from yak milk samples are shown in Figure 2 (middle and outer ring).

Their 16S rRNAgene sequence analysis further revealed high similarities with the strains of currently known species of $L b$. paracasei subsp. paracasei; however, when their phenotypic characters were compared with genotypic traits of $L b$. paracasei subsp. paracasei reported in literature elsewhere they showed diversification.

Lb. plantarum appeared as the second most frequent Lactobacillus species in the raw yak milk during the current study with a total number of 15 isolates. White, regular, smooth and convex

Table 1. Phenotypic traits of lactic acid bacteria (LAB) isolated from yak milk tested by the API $50 \mathrm{CHL}$ system

\begin{tabular}{|c|c|c|c|c|c|c|c|c|c|}
\hline $\begin{array}{l}\text { Designated } \\
\text { species }\end{array}$ & $\begin{array}{l}\text { Lb. paracasei- } \\
\text { subsp. tolerans }\end{array}$ & $\begin{array}{l}\text { Lb. } \\
\text { plantarum }\end{array}$ & $\begin{array}{l}\text { Lb. } \\
\text { casei }\end{array}$ & $\begin{array}{l}\text { Lb. delbreuckii } \\
\text { subsp. bulgaricus }\end{array}$ & $\begin{array}{l}\text { Lb. } \\
\text { sakei }\end{array}$ & $\begin{array}{l}\text { Lc. } \\
\text { lactis }\end{array}$ & $\begin{array}{l}\text { E. } \\
\text { durans }\end{array}$ & $\begin{array}{l}\text { E. } \\
\text { faecium }\end{array}$ & $\begin{array}{l}\text { E. } \\
\text { hirae }\end{array}$ \\
\hline No. of isolates & 17 & 15 & 8 & 6 & 3 & 7 & 15 & 10 & 7 \\
\hline Gram & positive & positive & positive & positive & positive & positive & positive & positive & positive \\
\hline Catalase & negative & negative & negative & negative & negative & negative & negative & negative & negative \\
\hline Shape & convex & convex & convex & regular/apparent & shiny convex & pinpoint & $\begin{array}{l}\text { small } \\
\text { emerged }\end{array}$ & $\begin{array}{l}\text { small } \\
\text { emerged }\end{array}$ & $\begin{array}{l}\text { small } \\
\text { emerged }\end{array}$ \\
\hline Colour & greyish-white & white & greyish-white & greyish-white & creamy white & off-white & white & white & white \\
\hline Surface & smooth & smooth & smooth & smooth & smooth & smooth & smooth & smooth & smooth \\
\hline Margins & regular & regular & regular & regular & regular & regular & regular & regular & regular \\
\hline Cell shape & $\begin{array}{l}\text { rods/square } \\
\text { ends/single/ } \\
\text { chains }\end{array}$ & $\begin{array}{l}\text { rods/rounded } \\
\text { ends/singe/ } \\
\text { chains }\end{array}$ & $\begin{array}{l}\text { rods/square } \\
\text { ends/single/ } \\
\text { chains }\end{array}$ & $\begin{array}{l}\text { long curled rods } \\
\text { chains }\end{array}$ & $\begin{array}{l}\text { rods/short } \\
\text { chains/ } \\
\text { rounded ends }\end{array}$ & $\begin{array}{l}\text { ovoid/ } \\
\text { cocci in } \\
\text { chains }\end{array}$ & $\begin{array}{l}\text { cocci in } \\
\text { chains }\end{array}$ & $\begin{array}{l}\text { cocci in } \\
\text { chains }\end{array}$ & $\begin{array}{l}\text { cocci in } \\
\text { chains }\end{array}$ \\
\hline \multicolumn{10}{|l|}{ Growth at: } \\
\hline $10^{\circ} \mathrm{C}$ & $N / D$ & $\mathrm{~N} / \mathrm{D}$ & $N / D$ & $N / D$ & $N / D$ & + & + & + & + \\
\hline $15^{\circ} \mathrm{C}$ & + & + & + & - & + & + & + & + & + \\
\hline $45^{\circ} \mathrm{C}$ & - & - & - & + & - & - & + & + & + \\
\hline \multicolumn{10}{|l|}{ Carbohydrates fermentation } \\
\hline arabinose & - & + & - & $\mathrm{N} / \mathrm{D}$ & + & - & - & + & - \\
\hline D-arabinose & - & - & - & - & - & - & - & + & - \\
\hline L-arabinose & - & + & - & + & + & - & - & + & - \\
\hline xylose & - & + & - & - & - & - & - & + & - \\
\hline ribose & - & + & + & + & + & + & + & + & + \\
\hline sucrose & - & + & + & - & + & $3^{*}$ & $d$ & $d$ & $d$ \\
\hline maltose & - & + & + & - & + & + & + & + & + \\
\hline cellobiose & - & + & + & + & + & + & + & + & + \\
\hline trehalose & - & + & + & + & + & + & + & + & + \\
\hline melibiose & - & + & - & + & + & - & $d$ & $d$ & $d$ \\
\hline raffinose & - & 10 & - & + & - & - & - & - & 4 \\
\hline melizitose & - & + & + & - & - & - & - & - & - \\
\hline dextrin & $N / D$ & + & + & $N / D$ & $N / D$ & - & $N / D$ & 7 & $N / D$ \\
\hline inulin & - & + & + & $N / D$ & - & - & - & - & - \\
\hline mannitol & - & + & + & - & - & - & - & 5 & - \\
\hline esculin & - & + & + & + & 1 & + & + & + & + \\
\hline salicin & - & + & + & + & + & + & + & + & - \\
\hline amygdalin & - & + & + & + & 2 & + & + & + & + \\
\hline starch & - & 3 & - & - & - & - & - & - & - \\
\hline gluconate & + & + & + & - & + & 2 & - & $d$ & - \\
\hline sorbitol & - & + & + & + & - & - & - & $d$ & $N / D$ \\
\hline dulcitol & - & - & - & + & - & - & - & - & - \\
\hline glycerol & - & - & - & - & - & - & - & $d$ & $d$ \\
\hline D-tagatose & + & 8 & + & - & + & - & - & $d$ & $d$ \\
\hline D-xylose & - & - & - & 1 & - & - & - & $d$ & - \\
\hline L-xylose & - & $d$ & - & - & - & - & - & - & - \\
\hline D-turanose & - & - & - & + & + & - & - & - & + \\
\hline$\alpha$-methyl-D-mannoside & $N / D$ & - & $N / D$ & $N / D$ & - & - & $N / D$ & - & $N / D$ \\
\hline$\alpha$-methyl-L-glucoside & $N / D$ & - & + & $N / D$ & - & - & N/D & - & - \\
\hline$N$-acetylglucosamine & $N / D$ & + & $N / D$ & - & - & + & + & 3 & + \\
\hline
\end{tabular}

positive reaction $(+)$, negative reaction $(-)$, not determined $(N / D) ;{ }^{*}-$ number of strains able to ferment, $d$ - delayed fermentation 
colonies were observed with straight rods morphology occurring singly, in pairs or short chains usually with rounded ends. Species recognized as Lb. plantarum fermented arabinose, L-arabinose, xylose, ribose, sucrose, maltose, cellobiose, trehalose, melibiose, melizitose, dextrin, inulin, mannitol, esculin, salicin, amygdalin, gluconate, sorbitol, $N$-acetylglucosamine. Starch was fermented by only 3 strains, D-tagatose by 8 strains and raffinose was fermented by 10 strains out of 15 tested strains.

The isolation phase in the current study further revealed the isolation of other important Lactobacillus species such as Lb. casei, Lb. delbrueckii subsp. bulgaricus and Lb. sakei $(9,7$ and 3\%, respective1y). Their phenotypic and biochemical characteristics are reflected in Table 1 . In the current study, 6 strains were determined as Lb. delbuerckii subsp. bulgaricus. Overall, the lowest frequency was observed for $L b$. sakei as compared to other LAB isolated from yak milk.

It was further observed during the current study that different species of Enterococcus genus showed different pattern based on their colony morphology, followed by their gram straining and showed visible growth at different temperature. This variation in their morphology, phenotypic and sugar fermentation results may be due to their genetic make-up.
A total of 39 isolates were partially identified as enterococci from raw yak milk. Initially, they were differentiated from other cocci species based on their ability to ferment mannitol and growth at $45{ }^{\circ} \mathrm{C}$. E. durans appeared as the major species among enterococci accounting to $17 \%$ of the total LAB strains followed by E. faecium that account to $11 \%$ of the total isolated LAB from yak milk samples. The third species identified in the current study through complete biochemical characterization and 16S rRNA gene sequencing analysis among Enterococcus group was E. hirae. Their total share among the LAB isolated from the present study was $8 \%$. Their 16S rRNA analysis showed 97-99\% similarities with the sequences of the data bank.

The studied characteristics suggested that all the Lactococcus strains isolated in the current study belonged to Lc. lactis. They have smooth circular colonies, contrary to enterococci they were unable to ferment mannitol and grow at $45^{\circ} \mathrm{C}$.

All isolates yielded a single, clear fragment of $1.5 \mathrm{~kb}$, as shown in Figure 3. Only 30 bacterial isolates that showed promising results for antibacterial attributes during the current study were further identified genotypically through the analysis of their 16S rRNA gene sequencing. Later their probiotic potential was also accessed

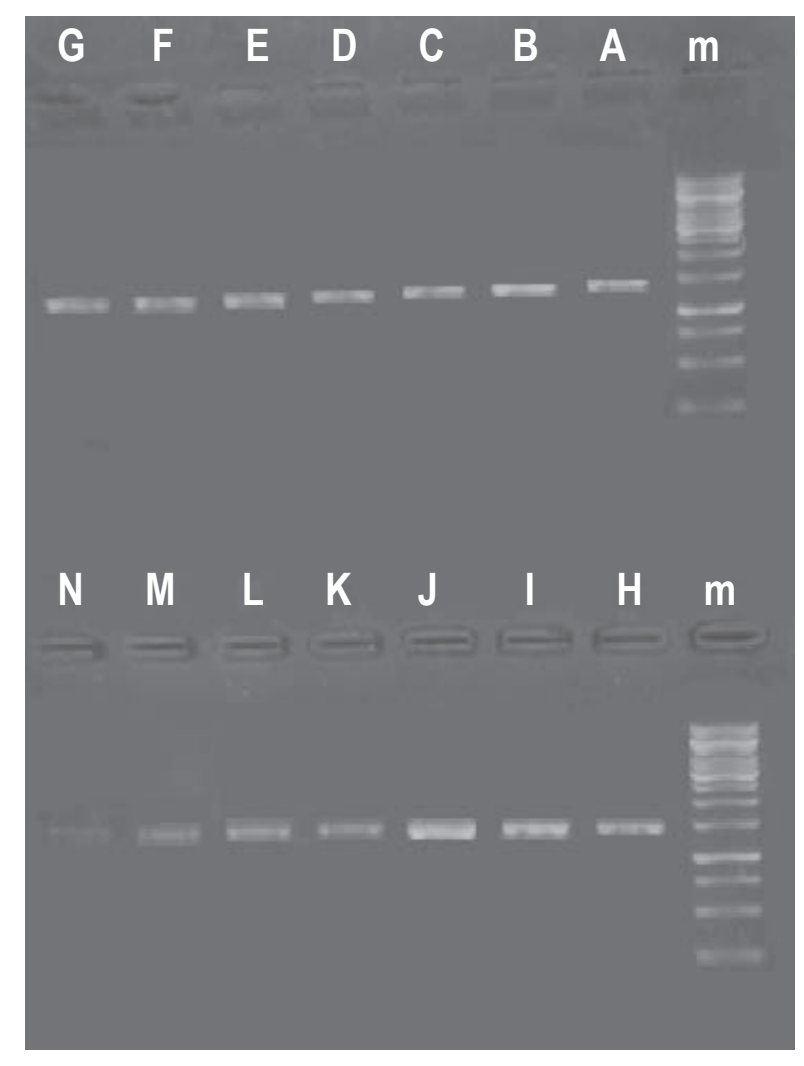

Figure 3. PCR amplified 16S rRNA gene products of the representative isolates of lactic acid bacteria (LAB) isolated from yak milk (A to N) showing $1.5 \mathrm{~kb}$ product along with the marker $(\mathrm{m})(1 \mathrm{~kb}$; Thermo Fischer Scientific, Waltham, MO, USA). 
(data related to probiotic properties not shown). The 16S rRNA sequences analysed of these strains revealed high levels of similarity with the type strains of current known species in the database, for remaining 15 isolates the similarity values were below $98 \%$, among these 4 strains showed $97 \%$ similarity with type strains while a single strain E. faecium (MAQ-39) exhibited the lowest $(95 \%)$ similarity as reflected in Figure 4. 16S rRNA sequences reported in the current study are deposited in the repository and accession numbers assigned for thirty sequences are consecutive numbers from MF446917 to MF446946 as shown in Table 2.

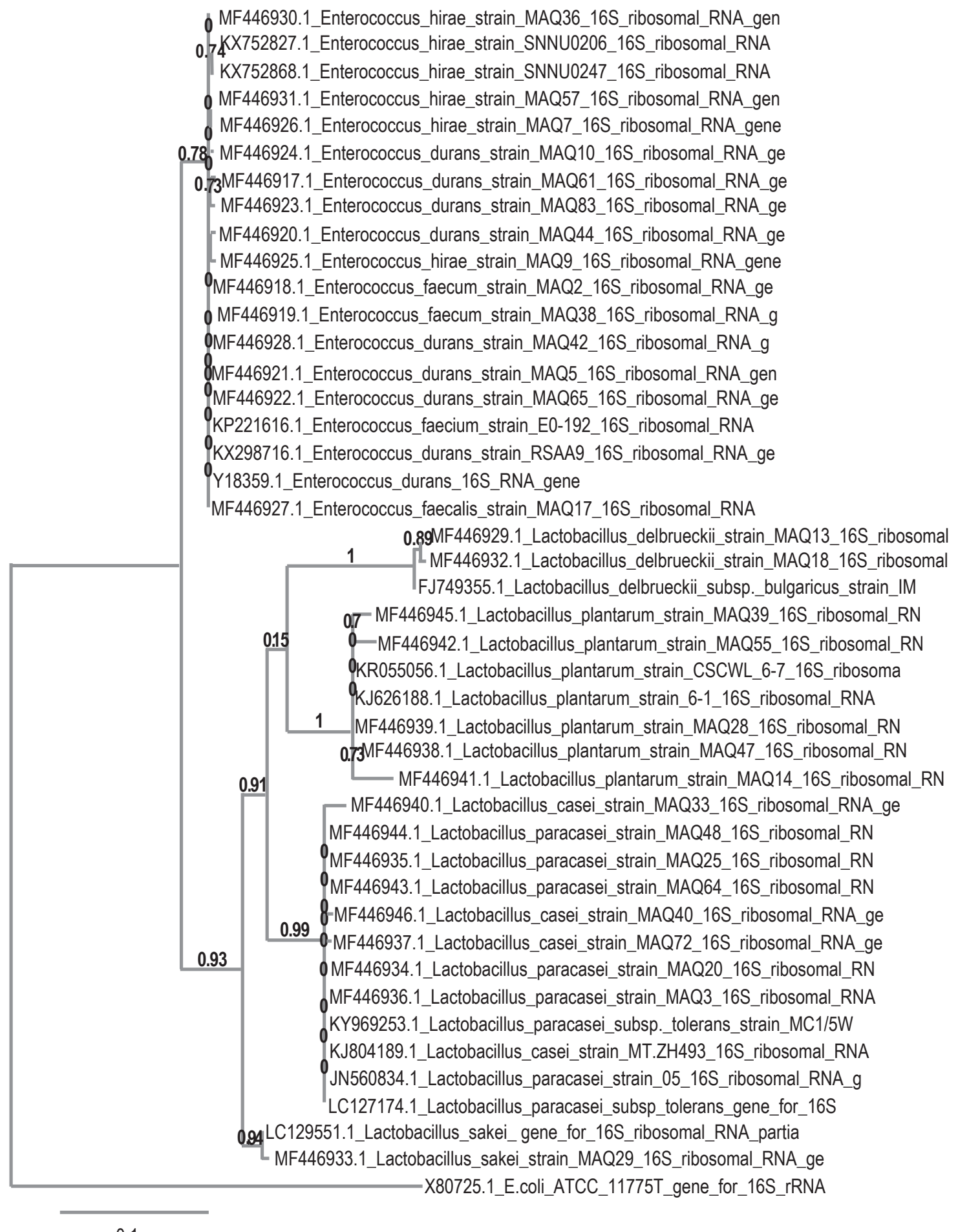

Figure 4. The phylogenetic tree constructed neighbour-joining method showing the phylogenetic relationship of 30 isolates and type strains based on 16S rRNA gene sequences. E. coli ATCC_117775T was used as an outgroup. 
Table 2. Identification of lactic acid bacteria (LAB) isolated from yak milk through 16S rRNA gene sequencing

\begin{tabular}{|c|c|c|c|c|c|}
\hline $\begin{array}{l}\text { Strain } \\
\text { No. }\end{array}$ & Isolate & $\begin{array}{l}\text { No. of nucleotides } \\
\text { of } 16 \mathrm{~S} \text { rRNA gene }\end{array}$ & $\begin{array}{l}\text { Accession } \\
\text { No. of strain }\end{array}$ & Nearest match species from DDBJ & $\begin{array}{l}\text { Similarity, } \\
\%\end{array}$ \\
\hline 1 & MAQ-3 & 1378 & MF446936 & LC127174_1 Lb. paracasei subsp. tolerans 16S ribosomal RNA & 100 \\
\hline 2 & MAQ-20 & 1376 & MF446934 & KY969253_1 Lb. paracasei subsp. tolerans $16 \mathrm{~S}$ ribosomal RNA & 99 \\
\hline 3 & $M A Q-25$ & 1331 & MF446935 & LC127174_1 Lb. paracasei subsp. tolerans 16S ribosomal RNA & 99 \\
\hline 4 & MAQ-48 & 1367 & MF446944 & LC127174_1 Lb. paracasei subsp. tolerans 16S ribosomal RNA & 99 \\
\hline 5 & $M A Q-64$ & 1375 & MF446943 & JN560834_1 Lb. paracasei subsp. tolerans 16 S ribosomal RNA & 99 \\
\hline 6 & MAQ-14 & 1368 & MF446941 & KX056618_1 Lb. plantarum 16S ribosomal RNA & 97 \\
\hline 7 & MAQ-28 & 1376 & MF446939 & KJ626188_1 Lb. plantarum 16S ribosomal RNA & 98 \\
\hline 8 & MAQ-39 & 1381 & MF446945 & KR055056_1 Lb. plantarum 16S ribosomal RNA & 95 \\
\hline 9 & $M A Q-47$ & 1381 & MF446938 & KJ626188_1 Lb. plantarum 16S ribosomal RNA & 99 \\
\hline 10 & MAQ-55 & 1306 & MF446942 & KX057543_1 Lb. plantarum 16S ribosomal RNA & 98 \\
\hline 11 & MAQ-33 & 1387 & MF446940 & KJ804189_1 Lb. casei 16S ribosomal RNA & 98 \\
\hline 12 & $M A Q-40$ & 1388 & MF446946 & KU955827_1 Lb. casei 16 S ribosomal RNA & 99 \\
\hline 13 & MAQ-72 & 1382 & MF446937 & KF673512_1 Lb. casei 16S ribosomal RNA & 98 \\
\hline 14 & $M A Q-13$ & 1371 & MF446929 & FJ749355_1 Lb. delbrueckii subsp. bulgaricus Strain IMAU40080 16S rRNA gene & e 98 \\
\hline 15 & $M A Q-18$ & 1362 & MF446932 & FJ749732_1 Lb. delbrueckii subsp. bulgaricus 16 S ribosomal RNA & 99 \\
\hline 16 & MAQ-29 & 1381 & MF446933 & LC129551_1 Lb. sakei 16S ribosomal RNA & 99 \\
\hline 17 & MAQ-5 & 1367 & MF446921 & KX298716_1 E. durans 16S ribosomal RNA & 99 \\
\hline 18 & $M A Q-10$ & 1369 & MF446924 & Y18359_1E. durans 16S ribosomal RNA & 98 \\
\hline 19 & $M A Q-42$ & 1351 & MF446928 & Y18359_1 E. durans 16S ribosomal RNA & 98 \\
\hline 20 & MAQ-44 & 1373 & MF446920 & LT853599.1 E. durans partial 16S rRNA gene strain & 99 \\
\hline 21 & $M A Q-61$ & 1387 & MF446917 & Y18359_1 E. durans 16S ribosomal RNA & 98 \\
\hline 22 & $M A Q-65$ & 1382 & MF446922 & KX298716_1 E. durans 16S ribosomal RNA & 98 \\
\hline 23 & MAQ-83 & 1356 & MF446923 & Y18359_1E. durans 16S ribosomal RNA & 99 \\
\hline 24 & MAQ-2 & 1049 & MF446918 & KX88173_1 E. faecium Unkn755 16S ribosomal RNA & 99 \\
\hline 25 & $M A Q-17$ & 1338 & MF446927 & FJ481129_1 E. faecium 16S ribosomal RNA & 99 \\
\hline 26 & MAQ-38 & 1363 & MF446919 & KP221616_1 E. faecium Strain E-192 16S ribosomal RNA & 99 \\
\hline 27 & MAQ-7 & 1393 & MF446926 & KX752830_1 E. hirae 16 S ribosomal RNA & 97 \\
\hline 28 & $M A Q-9$ & 1359 & MF446925 & KX752827_1 E. hirae 16 S ribosomal RNA & 99 \\
\hline 29 & $M A Q-36$ & 1368 & MF446930 & KU198313_1 E. hirae 16S ribosomal RNA & 98 \\
\hline 30 & MAQ-57 & 1379 & MF446931 & KX752868_1 E. hirae 16 S ribosomal RNA & 97 \\
\hline
\end{tabular}

DDBJ - DNA Data Bank of Japan

\section{Discussion}

Fresh yak milk samples (33) were analysed on selective media to determine the indigenous community of LAB in 3 different districts. Although the distribution of yak has been reported in 7 of total 10 districts in Gilgit-Baltistan, the sampling areas for the current study were selected to avoid sampling from crossbreeds of yak, as many of nonsampling areas are reported to hold crossbreeds of yak. In an earlier report, Bao et al. (2012) also reported the higher recovery of LAB from MRS agar. Different numbers of LAB isolates have been reported in previous studies, as Zhang et al. (2011) isolated $71 \mathrm{LAB}$ from 15 samples of processed yak milk collected from pastures in Gansu, China, while in an earlier study Sun et al. (2010) sequenced 196 LAB from Kurut made from yak milk in Qinghai, China. Various biotic and abiotic drivers may govern the establishment of core microbiota in raw milk.
Among the LAB, Lactobacillus is considered as the largest genus consisting of 196 valid species. These have been recovered from various habitats including mammalian intestinal tracts, raw milk, plant sources, sewage and dairy products. Previously, the dominance of Lactobacillus from traditionally fermented yak milk products in the Tibet region of China was reported by Ren et al. (2017). Bao et al. (2012) also classified 51.41\% LAB as Lactobacillus from raw yak milk and traditional yak milk products. Similarly, Airidengcaicike et al. (2010) reported Lactobacillus as the dominating genus among cultivable LAB isolated from fermented milk in Tibet of China. Based on these observations it could be assumed that the yak milk is an excellent media to support the growth of Lactobacillus species. To the best of our knowledge, this is the first report to isolate Lb. paracasei subsp. tolerans species from yak milk. This could be attributed to the unique geographical and climatic habitat of yak in the current sampling areas. Another great contributing factor to influence 
the specific microbial composition of yak milk may be the exclusive chemical composition of yak milk reportedly with higher fat, crude protein, dry matter and lactose content. Previously this species of LAB have been reported from various sources including yoghurt, sourdough bread culture, pepper leaves, cow milk and Ramnogaster arcuate. They are known to survive the pasteurization temperature of $72^{\circ} \mathrm{C}$ up to $40 \mathrm{~s}$; however, when their phenotypic characters were compared with phenotypic traits of Lb. paracasei subsp. paracasei they showed diversification. The environmental conditions along with isolate's ability to change plasmid encodings for carbohydrate fermentation metabolism can result in a typical metabolic feature. This means that established identification methods can be imprecise favouring the use of molecular taxonomic methods for identification of Lactobacillus isolates.

Lactobacillus plantarum is one of the most important species of Lactobacillus genus. This species has been observed in different environmental niches like dairy products, vegetables and meat. Zhang et al. (2011) also reported Lb. plantarum as the most dominant species among LAB isolated from 15 traditional fermented yak milk samples. Our observations are in accordance with the report of Marroki et al. (2011) who isolated and characterized LAB from Algerian goat milk and reported $\mathrm{Lb}$. plantarum as the largest group of LAB after conforming their identification through API 50 CHL kits. Similar results were also observed by Dewan and Tamang (2007) for Lb. plantarum strains identified among dominant LAB from Himalayan ethnic fermented milk products.

The isolation phase in the current study resulted in the isolation of other important Lactobacillus species including $L b$. casei, Lb. delbrueckii subsp. bulgaricus and $L b$. sakei ( 9,7 and $4 \%$, respectively). The current observations coincide with Zhang et al. (2011) who reported the isolation of $L b$. casei from fermented yak milk. $L b$. casei has been successfully applied as a probiotic culture in traditional fermented kinds of milk, cheeses and commercially fermented foods. World-famous $L b$. casei strain (Shirota) has been applied in food fermentations as a probiotic culture to enhance consumer health. Similarly, two strains $\mathrm{C} 1$ and $\mathrm{Y}$ as promising probiotic culture for the development of fermented milk were reported by Mishra and Parsad (2005).

Lactobacillus bulgaricus species can be widely isolated from several dairy products. Previously Van de Casteele et al. (2006) concluded MRS as the most ideal medium for the isolation of $L b$. delbrueckii subsp. bulgaricus. Bao et al. (2012) detected Lb. delbrueckii subsp. bulgaricus in yak milk products. In a more recent study, Ren et al. (2017) reported Lb. delbrueckii subsp. bulgaricus as the most commonly isolated species from fermented yak milk in Tibet. Streptococcus thermophilus and Lb. delbrueckii subsp. bulgaricus are the most significant species used as dairy starter cultures. A strain of $L b$. delbrueckii subsp. bulgaricus (ND02) isolated from naturally fermented yak milk has been implemented in the production of dairy starter cultures by the largest dairy corporation in China (Sun et al., 2011). We recommend the exploitation of Lb. delbrueckii subsp. bulgaricus strains isolated during the current study as a potential starter culture for production of fermented dairy products.

Overall, the lowest abundance was observed for $L b$. sakei in comparison to other LAB isolated from yak milk. A similar trend was also observed by Ren et al. (2017) in fermented yak milk in Tibet region. The similarities of territorial conditions of the current study and Tibet region of China may be assumed responsible for a lower incidence of $L b$. sakei. This species was initially isolated from rice wine (sake). It is often isolated from vegetable sources; however, it is systematically associated with fermented meats and fish products. Lactobacillus sakei is gaining its importance in the food industry due to its role in the fermentation of sausages and its prevalence during cold storage of meat products (Zagorec and Champomier-Verges, 2017).

It is generally agreed that Enterococcus are cocci shaped, Gram-positive and catalase-negative bacteria belonging to gastrointestinal microflora and they have been isolated from different ecosystems. The genus Enterococcus is composed of 41 species. Their usual ecological niche is the human intestines; however, they can be found in soils, plants and dairy products. They may occur singly, in pairs or in chains as evident. They are homofermentative and produce lactic acid from glucose. Although their safety is controversial, they have a long history of safe use in food fermentations. Enterococcus faecium K775 is an Enterococcus strain that is approved as a commercial strain in Denmark as a starter culture (Gardiner et al., 1999). They may enter the food chain and dairy environment from other primary habitats including faeces, plants, soil, water and others. Their greater adaptability is attributed to their capability to grow under harsh environments like high salinity, extreme $\mathrm{pH}$ (4-9) and temperature $\left(10-45^{\circ} \mathrm{C}\right)$. Consequently, they may be found in dairy products that are made from raw materials including raw yak milk (Ogier and Serror, 2008).

In older reports, E. durans has been cited as a minority component of the human intestine; however, in later reports it has been found that $18 \%$ 
of the healthy people were carriers of E. durans (Blaimont et al., 1995). Ao et al. (2012) reported E. durans as the dominating species in traditional fermented yak milk (Xueo) in western Sichuan Plateau of China.

The observations of the current study are in agreement with the previous study by Oladipo et al. (2013) in which E. faecium was dominant species $(14.5 \%)$ among Nigerian fermented foods. In another study, E. faecium was detected as the predominant (61\%) species among Enterococcus species isolated from retail meats in Iowa (Hayes et al., 2003). The discrepancies between both studies may be due to different sources of foods taken for isolation of LAB. Their identification with the classical method was difficult therefore; they were identified with API $50 \mathrm{CH}$ kits. Our laboratory is currently working on the isolation and characterization of a bacteriocin produced by strain E. faecium MAQ-2.

Lactococci are coccus-shaped, Gram-positive and catalase-negative bacteria that were first suggested in 1985 after reclassification of specific species from genera of Lactobacillus and Streptococcus. Mesophilic Lactococci is often isolated from raw milk along with other dairy products. Lactococci lactis is mostly used as a starter culture in milk fermentation and new strains are being screened mostly from milk sources. Zamfir et al. (2006) reported them as the dominant $\mathrm{LAB}$ in fermented milk.

The partial identification of all the LAB isolates through classical methods was confirmed through the PCR amplification of 16S rRNA region of the isolates using a set of universal primers $(27 \mathrm{~F}$ and $1492 \mathrm{R})$. All the isolates yielded a single, clear fragment of $1.5 \mathrm{~kb}$, as shown in Figure 3. Similar observation has been reported by Park et al. (2010). Identification of LAB attained through the carbohydrate fermentation profile is not accurate and reliable as they share similar nutritional requirements. Therefore, 16S rRNA gene sequencing analysis has been used to decide the dynamics and diversity of LAB in foods. Only 30 bacterial isolates that showed promising results for antibacterial attributes during the current study were further identified genotypically through the analysis of their 16S rRNA gene sequences. Later their probiotic potentials were also accessed (data related to probiotic properties not shown). The sequence alignments were obtained by using the Bioedit assembly program. Homologies were determined with the nucleotide sequences previously deposited on DDBJ through the BLAST. Later, phylogenetic analysis was conducted using software MEGA (version 6.06) with neighbourjoining clustering method whereas analysis of the robustness of the tree was obtained by a bootstrap method with 1000 replicates (Figure 4). Therefore, the relatively lower similarities of the above strains suggest that they could be novel species.

\section{Conclusions}

The complex biodiversity of dominant lactic acid bacteria (LAB) was demonstrated for the first time in yak milk originating from 3 different districts of Gilgit-Baltistan, Pakistan. A total number of 88 strains were isolated comprising 3 genera and 9 species or subspecies through pure culture techniques and were further confirmed by API 50 $\mathrm{CH}$ system and 16S rRNA gene sequencing analysis. The diversity of LAB concluded that yak milk is a suitable habitat for various LAB. The lactobacilli (53.4\%) were found the most dominant and were followed by enterococci (41\%) and lactococci (5.6\%). Lactobacillus paracasei subsp. tolerans was detected as the predominant species. The current study also provides the basis for further exploration of these identified strains for their probiotic attributes and their application as starter components of fermented milk products, which are supposed to contribute to the consumer's needs for higher microbial safety along with better organoleptic, technological and nutritional properties.

\section{Acknowledgements}

The authors are thankful for the financial support of the Higher Education Commission of Pakistan for the current research project under the HEC Indigenous $5000 \mathrm{PhD}$ Fellowship Program Phase II, Batch-I (PIN: 112-21766-2AVI-336).

\section{Conflict of interest}

The authors declare that there is no conflict of interest.

\section{References}

Abdelgadir W.S., Hamad S.H., Møller P.L., Jakobsen M., 2001. Characterisation of the dominant microbiota of Sudanese fermented milk Rob. Int. Dairy J. 11, 63-70, https://doi. org/10.1016/S0958-6946(01)00042-5

Airidengcaicike, Chen X., Du X., Wang W., Zhang J., Sun Z., Liu W., Li L., Sun T., Zhang H., 2010. Isolation and identification of cultivable lactic acid bacteria in traditional fermented milk of Tibet in China. Int. J. Dairy Technol. 63, https://doi.org/10.1111/j.14710307.2010.00595.x 
Ao X., Zhang X., Zhang X., Shi L., Zhao K., Yu J., Dong L., Cao Y., Cai Y., 2012. Identification of lactic acid bacteria in traditional fermented yak milk and evaluation of their application in fermented milk products. J. Dairy Sci. 95, 1073-1084, https://doi. org/10.3168/jds.2011-4224

Bao Q.H., Liu W., Yu J. et al., 2012. Isolation and identification of cultivable lactic acid bacteria in traditional yak milk products of Gansu Province in China. J. Gen. Appl. Microbiol. 58, 95-105, https://doi.org/10.2323/jgam.58.95

Blaimont B., Charlier J., Wauters G., 1995. Comparative distribution of Enterococcus species in faeces and clinical samples. Microb. Ecol. Health Dis. 8, 87-92, https://doi. org/10.3109/08910609509140084

Chammas G.I., Saliba R., Corrieu G., Béal C., 2006. Characterisation of lactic acid bacteria isolated from fermented milk "laban". Int. J. Food Microbiol. 110, 52-61, https://doi.org/10.1016/j.jijfoodmicro.2006.01.043

Coeuret V., Dubernet S., Bernardeau M., Gueguen M., Vernoux J.P., 2003. Isolation, characterization and identification of lactobacillifocusing mainly on cheeses and other dairy products. Lait 83, 269-306, https://doi.org/10.1051/lait:2003019

Dewan S., Tamang J.P., 2007. Dominant lactic acid bacteria and their technological properties isolated from the Himalayan ethnic fermented milk products. Antonie Van Leeuwenhoek 92, 343-352, https://doi.org/10.1007/s10482-007-9163-5

Gardiner G.E., Ross R.P., Wallace J.M., Scanlan F.P., Jägers P.P., Fitzgerald G.F., Collins J.K., Stanton C., 1999. Influence of a probiotic adjunct culture of Enterococcus faeciumon the quality of cheddar cheese. J. Agric. Food Chem. 47, 4907-4916, https://doi.org/10.1021/jf990277m

Gran H.M., Gadaga H.T., Narvhus J.A., 2003. Utilization of various starter cultures in the production of Amasi, a Zimbabwean naturally fermented raw milk product. Int. J. Food Microbiol. 88, 19-28, https://doi.org/10.1016/S0168-1605(03)00078-3

Hall T., 1999. BioEdit: a user-friendly biological sequence alignment editor and analysis program for Windows 95/98/NT. Nucl. Acids Symp. Ser. 41, 95-98

Hayes J.R., English L.L., Carter P.J., Proescholdt T., Lee K.Y., Wagner D.D., White D.G., 2003. Prevalence and antimicrobial resistance of Enterococcus species isolated from retail meats. Appl. Environ. Microbiol. 69, 7153-7160, https://doi. org/10.1128/AEM.69.12.7153-7160.2003

Jasra A.W., Hashmi M.M., Waqar K., Ali M., 2016. Traditional yak herding in high-altitude areas of Gilgit-Baltistan, Pakistan: transboundary and biodiversity conservation challenges. In: W. Ning, Y. Shaoliang, S. Joshi, N. Bisht (Editors). Yak on the Move; Transboundary Challenges and Opportunities for Yak Raising in a Changing Hindu Kush Himalayan Region. International Centre for Integrated Mountain Development (ICIMOD). Kathmandu (Nepal), pp. 41-51

Kandler O., Weiss N., 1986. Genus Lactobacillus. In: P.H.A. Sneath, N.S. Mair, H.E. Sharpe, J.G. Holt (Editors). Bergey's Manual of Systematic Bacteriology, Volume 2, 9th Edition. Williams and Wilkins. Baltimore, MD (USA), pp. 1063-1065

Liu W., Bao Q., Jirimutuet et al., 2012. Isolation and identification of lactic acid bacteria from Tarag in Eastern Inner Mongolia of China by $16 \mathrm{~S}$ rRNA sequences and DGGE analysis. Microbiol. Res. 167, 110-115, https://doi.org/10.1016/j.micres.2011.05.001

Luming D., Ruijun L., Zhanhuan S., Changting W., Yuhai Y., Songhe X., 2008. Feeding behaviour of yaks on spring, transitional, summer and winter pasture in the alpine region of the Qinghai-Tibetan plateau. Appl. Anim. Behav. Sci. 111, 373-390, https://doi.org/10.1016/j.applanim.2007.06.008

Mahmood T., Masud T., Imran M., Ahmed I., Khalid N., 2013. Selection and characterization of probiotic culture of Streptococcus thermophillus from dahi. Int. J. Food Sci. Nutr. 64, 494-501, https:/l doi.org/10.3109/09637486.2012.749840
Marroki A., Zúñiga M., Kihal M., Pérez-Martínez G., 2011. Characterization of Lactobacillus from Algerian goat's milk based on phenotypic, 16S rDNA sequencing and their technological properties. Braz. J. Microbiol. 42, 158-171, https://doi.org/10.1590/S1517-83822011000100020

Mathara J.M., Schillinger U., Kutima P.M., Mbugua S.K., Holzapfel W.H., 2004. Isolation, identification and characterization of the dominant microorganisms of kule naoto: the Maasai traditional fermented milk in Kenya. Int. J. Food Microbiol. 94, 269-278, https://doi.org/10.1016/j.ijfoodmicro.2004.01.008

Mishra V., Prasad D.N., 2005. Application of in vitro methods for selection of Lactobacillus casei strains as potential probiotics. Int. J. Food Microbiol.103,109-115, https://doi.org/10.1016/j. ijfoodmicro.2004.10.047

Ogier J.-C., Serror P., 2008. Safety assessment of dairy microorganisms: The Enterococcus genus. Int. J. Food Microbiol. 126, 291-301, https://doi.org/10.1016/j.ijfoodmicro.2007.08.017

Oladipo I.C., Sanni A., Swarnakar S., 2013. Phenotypic and genomic characterization of Enterococcus species from some Nigerian fermented foods. Food Biotechnology. 27, 39-53, https://doi.or $\mathrm{g} / 10.1080 / 08905436.2012 .755627$

Park J.-M., Shin J.-H., Lee D.-W., Song J.-C., Suh H.-J., Chang U.-J., Kim J.-M., 2010. Identification of the lactic acid bacteria in Kimchi according to initial and over-ripened fermentation using PCR and 16S rRNA gene sequence analysis. Food Sci. Biotechnol. 19, 541-546, https://doi.org/10.1007/s10068-0100075-1

Ren Y., Yang Y., Zhang D., Wang D., Zhang H., Liu W., 2017. Diversity analysis and quantification of lactic acid bacteria in traditionally fermented yaks' milk products from Tibet. Food Biotechnol. 31, 1-19, https://doi.org/10.1080/08905436.2016.1269290

Sun Z., Chen X., Wang J. et al., 2011. Complete genome sequence of Lactobacillus delbrueckii subsp. bulgaricus strain ND02. J. Bacteriol. 193, 3426-3427, https://doi.org/10.1128/ JB.05004-11

Sun Z., Liu W., Gao W., Yeng M., Zhang J., Wu L., Wang J., Menghe B., Sun T., Zhang H., 2010. Identification and characterization of the dominant lactic acid bacteria from kurut: The naturally fermented yak milk in Qinghai, China. J. Gen. Appl. Microbiol. 56, 1-10, https://doi.org/10.2323/jgam.56.1

Tamura K., Stecher G., Peterson D., Filipinski A., Kumar S., 2013. MEGA6: Molecular Evolutionary Genetics Analysis version 6. Mol. Biol. Evol. 30, 2725-2729, https://doi.org.10.1093/molbev/ mst197

Van de Casteele S., Vanheuverzwijn T., Ruyssen T., Van Assche P., Swings J., Huys G., 2006. Evaluation of culture media for selective enumeration of probiotic strains of lactobacilli and bifidobacteria in combination with yoghurt or cheese starters. Int. Dairy J. 16, 1470-1476, https://doi.org/10.1016/j. idairyj.2005.12.002

Zagorec M., Champomier-Vergès M.-C., 2017. Lactobacillus sakei: a starter for sausage fermentation, a protective culture for meat products. Microorganisms 5, 56, https://doi.org/10.3390/ microorganisms 5030056

Zamfir M., Vancanneyt M., Makras L., Vaningelgem F., Lefebvre K., Pot B., Swings J., De-Vuyst L., 2006. Biodiversity of lactic acid bacteria in Romanian dairy products. Sys. Appl. Microbiol. 29, 487-495, https://doi.org/10.1016/j.syapm.2005.10.002

Zhang L., Yu Q., Han L., Zhang M., Yang L., Li Y.P., 2011. Evaluation of the potential probiotic properties of Lactobacillus strains isolated from traditional fermented yak milk. J. Food Agric. Environ. 9, 18-26 